\title{
INFLUENZA VIRUS INFECTION OF NEWBORN RATS: VIRULENCE OF RECOMBINANT STRAINS PREPARED FROM INFLUENZA VIRUS STRAIN A/OKUDA/57
}

\author{
C. Teh, R. Jennings and C. W. Potter \\ Department of Virology, Academic Division of Pathology, \\ University of Sheffield Medical School, Sheffield S10 2RX
}

Previous studies from this laboratory have investigated the effects of influenza viruses in infant rats as a possible method for assessing their virulence for man, and a series of virulent, attenuated and recombinant virus strains have been examined in this model (Michaels et al., 1978; Mahmud et al., 1979 $a$ and $b$ ). The results indicated that virulent strains replicated to significantly higher titre in rat turbinates than did attenuated strains. In addition, infection with virulent strains promoted subsequent systemic infection by Haemophilus influenzae inoculated intranasally, whilst attenuated strains did not have this property to the same degree. To date, 19 strains of influenza virus have been studied in infant rats, and the results for 18 have agreed with those obtained in volunteers; the exception was strain A/PR/8/34 which, though not infective for man (Beare and Hall, 1971), multiplied to high titre and promoted subsequent bacterial infection. The value of the infant rat for measuring the virulence of influenza virus for man can be assessed only by observation of a large series of virus strains of varying virulence. In the present report, we present the results for another 14 strains of virus. These are influenza virus strain A/Okuda/57 and recombinant viruses prepared from it; the series is distinct from the recombinants of strains A/PR/8/34 or A/Ann Arbor/66-7PI examined previously (Mahmud et al., 1979b).

\section{MATERIALS AND METHODS}

Virus strains. Influenza virus strains A/Finland/74(H3N2), A/Hong Kong/119/77(H1N1), A/Hong Kong/123/77 (H1N1), A/USSR/92/77 (H1N1), A/Hong/Kong/77 (H1N1-X2 cloned isolate) and A/Okuda/57 (H2N2) were kindly supplied by Dr G. Appleyard, Wellcome Research Laboratories, Beckenham, Kent; the A/Okuda/57 strain has been extensively studied and used in the production of recombinant strains for use as live vaccines for man (Morris et al., 1975; Freestone et al., 1976). Influenza virus strain WRL105 (H3N2) a recombinant of strains A/Finland/74 and A/Okuda/57, and influenza viruses strains WRL206 (H1N1), WRL211(H1N1), WRL215 (H1N1), WRL216 (H1N1), WRL217 (H1N1) and WRL224 (H1N1), all recombinants of strains A/Hong/Kong/119/77 (X2 cloned) and A/Okuda/57, were also supplied by Dr Appleyard. Influenza virus strains A/Victoria/3/75 (H3N2) and 4A2 (H3N2) were obtained from Dr A. S. Beare, Common Cold Research Centre, Salisbury, Wilts; these were used as control virulent and attenuated strains respectively, in all tests as described previously (Mahmud et al., 1979b). Virus pools were prepared by the allantoic inoculation of 10-day embryonated eggs. After incubation at $33^{\circ} \mathrm{C}$ for $72 \mathrm{~h}$, the allantoic fluids were collected 
and stored at $-80^{\circ} \mathrm{C}$. The infectivity titre of each virus pool was determined by titration in 10-day embryonated eggs, and the titres were calculated by the method of Reed and Muench (1938).

Experimental procedures. The methods to determine the titre of influenza virus in the lungs and turbinates of infant rats after intranasal inoculation, and the assessment of systemic infection by $H$. influenzae type b (HIb) have been described previously (Michaels et al., 1978; Mahmud et al., 1979a). Briefly, infant rats aged $48 \mathrm{~h}$ were given intranasal inoculation with 0.01 $\mathrm{ml}$ of phosphate buffered saline (PBS), $p \mathrm{H} \mathrm{7.4)}$ containing $10^{4}$ EID50 of influenza virus. At intervals after virus inoculation, groups of rats were killed and the lungs and turbinates removed; these tissues were individually ground with carborundum powder to give a $20 \%(\mathrm{v} / \mathrm{v})$ suspension in PBS containing $1.0 \%$ bovine serum albumen and antibiotics, centrifuged at 3000 r.p.m. for 20 min. at $4^{\circ} \mathrm{C}$, and the supernatant fluids titrated for virus by the allantois-on-shell (AOS) method (Fazekas de St Groth, Withell and Lafferty, 1958). A second group of rats was inoculated intranasally with $10^{5}-10^{6}$ colony-forming units (c.f.u.) of HIb in $0.01 \mathrm{ml}$ of PBS $48 \mathrm{~h}$ after virus inoculation. Three days later, these animals were killed, decapitated and a sample of freerunning blood collected in a capillary tube; 1 in 10 dilution of blood was prepared in PBS, and the concentration of HIb was measured by viable counting on chocolate agar. At the same time, the rat heads were removed and skinned, and fixed in buffered formalin for 5-7 days; after fixation, the heads were decalcified, processed and sectioned; the sections were stained by haemotoxylin and eosin and examined histologically for evidence of bacterial meningitis.

RNA analysis of influenza viruses. The analysis of the RNA of the recombinant influenza viruses, and the identification of the parental origin of each RNA fragment, was done by Dr A.J. Hay and Dr J. J. Skehel, National Institute for Medical Research, Mill Hill, London, by a hybridisation technique (Hay et al., 1977), who kindly made the results of these studies available to us.

\section{RESULTS}

\section{Replication of influenza viruses in infant-rat turbinates and lungs}

The growth of 15 strains of influenza virus, including four naturally occurring strains, two naturally occurring strains used as parents for the preparation of potential recombinant live vaccine viruses, seven recombinant strains, and control influenza strains A/Victoria/3/75 and 4A2, was studied in the turbinates and lungs of infant rats. The results are shown in table I. The titres of virus found in turbinate extracts of rats inoculated with strains A/Finland/74 and WRL 105 were $>10^{5}$ EBID50/ml at 24 and $48 \mathrm{~h}$, post-inoculation (p.i.). Influenza strains A/Hong Kong/123/77 and WRL206 gave lower titres; for these, titres of $10^{5} \mathrm{EBID} 50 / \mathrm{ml}$ were found $48 \mathrm{~h}$ but not $24 \mathrm{~h}$ after virus infection. In contrast, all the other viruses tested replicated to relatively low titre, and at neither 24 nor $48 \mathrm{~h}$ p.i. were titres of $>10^{5} \mathrm{EBID} 50 / \mathrm{ml}$ observed. The titres of virus found 5 days were more variable than those seen $1-2$ days p.i. For some strains, virus was identified in turbinate extracts throughout the period of observation, whilst for other strains virus was undetected at day 5, even in studies of strains showing relatively high titres of virus 48 hours p.i. (table I).

The titres of virus in lung extracts were more variable than in turbinate extracts; in addition, the results were highly individual and showed no apparent pattern (table I). Thus, relatively high titres of virus were found in the lungs of infant rats inoculated with strains A/Finland/74 and WRL105, which were the two viruses that gave the highest titres in turbinate extracts; virus was 


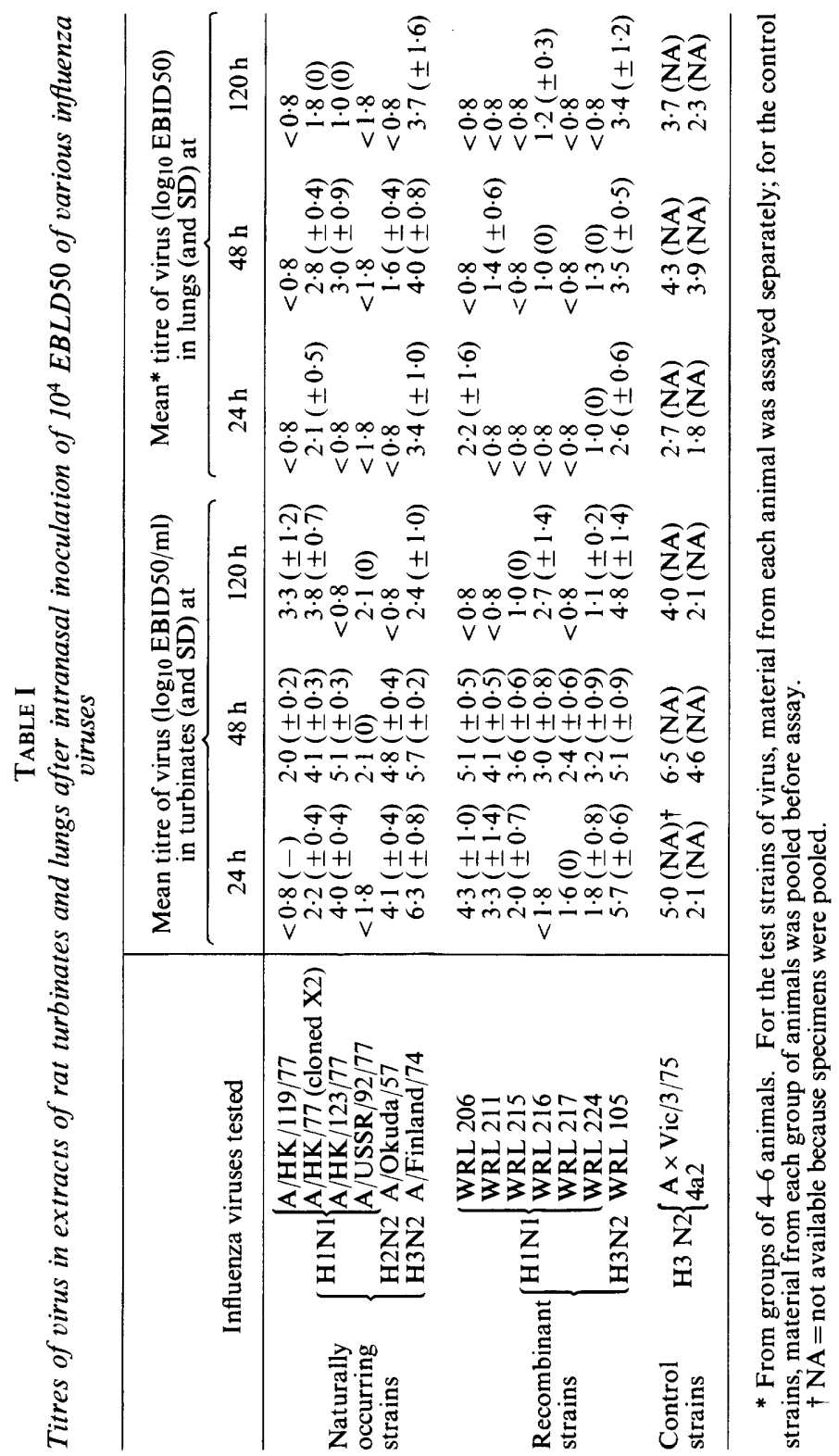


not detected at any time during the observation period in lung extracts of rats inoculated with strain A/Hong Kong/119/77, A/USSR/92/77, WRL215 or WRL217. Virus of strains WRL206 and WRL224 was detected in lung extracts 24 or $48 \mathrm{~h}$, but not 5 days p.i.; and virus was not detected in lung extracts $24 \mathrm{~h}$ but was detected $48 \mathrm{~h}$ and 5 days after inoculation with strain A/Hong Kong/123/77 (table I).

Two control viruses were studied in parallel with the above experiments; these were virulent strains $\mathrm{A} /$ Victoria/75 and attenuated $4 \mathrm{~A} 2$; the results obtained with these were similar to those found in previous studies (Mahmud et al., 1979b). Thus, strain A/Victoria $/ 3 / 75$ grew to $>10^{5} \mathrm{EBID} 50 / \mathrm{ml}$ at 24 and $48 \mathrm{~h}$ p.i. in rat turbinates, and was present at $>10^{2 \cdot 7} \mathrm{EBID} 50 / \mathrm{ml}$ in lung homogenates collected at 24, 48 and 120 hours p.i.; in contrast, strain $4 \mathrm{~A} 2$ replicated to lower titres in turbinates than did $\mathrm{A} /$ Victoria/75, but these strains behaved similarly in rat lungs (table I).

\section{$H$. influenzae type $b$ infection in rats pre-infected with influenza viruses}

Forty-eight hours after infection with $10^{4}$ EID50 of influenza virus, each rat was given an inoculation of $4.0-4.5 \times 10^{5}$ c.f.u. of $\mathrm{HIb}$; the incidence of bacteraemia and meningitis in these animals was determined $48 \mathrm{~h}$ after bacterial infection. The results are shown in table II. For rats previously inoculated with strain A/Finland/74 or WRL105 a relatively high incidence of bacteraemia was found, with $92 \%$ and $77 \%$ respectively of animals having

TABLE II

Incidence of bacteraemia and meningitis in rats after infection with influenza virus and subsequent inoculation of Haemophilus influenzae type $b$ (HIb)

\begin{tabular}{|c|c|c|c|c|}
\hline & \multirow[b]{2}{*}{ Influenza viruses tested } & \multirow{2}{*}{$\begin{array}{l}\text { Amount of HIb } \\
\text { inoculated } \\
\text { (c.f.u. } / 0.01 \mathrm{ml} \text { ) }\end{array}$} & \multicolumn{2}{|c|}{$\begin{array}{l}\text { Number of rats with } \mathrm{HIb} \\
\text { infection/number in } \\
\text { group (and percentage) } \\
\text { developing }\end{array}$} \\
\hline & & & bacteraemia & meningitis \\
\hline $\begin{array}{l}\text { Naturally } \\
\text { occurring } \\
\text { strains }\end{array}$ & $\left\{\begin{array}{l}\text { A/HK/119/77 } \\
\text { H/NK/H/77 (cloned X2) } \\
\text { A/H/HK/123/77 } \\
\text { A/H/USSR/92/77 } \\
\text { A/USSR } \\
\text { H2N2 A/Okuda/57 } \\
\text { H3N2A/Finland/74 }\end{array}\right.$ & $\begin{array}{l}4.5 \times 10^{5} \\
4.0 \times 10^{5} \\
4 \cdot 0 \times 10^{5} \\
4.5 \times 10^{5} \\
4.0 \times 10^{5} \\
4.0 \times 10^{5}\end{array}$ & $\begin{array}{r}1 / 12(8) \\
7 / 13(54) \\
4 / 12(33) \\
2 / 10(20) \\
1 / 13(8) \\
11 / 12(92)\end{array}$ & $\begin{array}{l}0 / 12(0) \\
3 / 13(23) \\
1 / 12(8) \\
1 / 10(10) \\
0 / 13(0) \\
9 / 12(75)\end{array}$ \\
\hline $\begin{array}{l}\text { Recombinant } \\
\text { strains. }\end{array}$ & 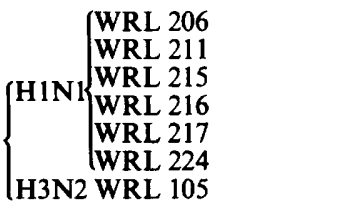 & $\begin{array}{l}4.5 \times 10^{5} \\
4.0 \times 10^{5} \\
4.0 \times 10^{5} \\
4.0 \times 10^{5} \\
4.0 \times 10^{5} \\
4.0 \times 10^{5} \\
4.0 \times 10^{5}\end{array}$ & $\begin{array}{r}4 / 11(36) \\
2 / 10(20) \\
3 / 16(19) \\
3 / 13(23) \\
3 / 13(23) \\
2 / 12(17) \\
10 / 13(77)\end{array}$ & $\begin{array}{l}1 / 11(9) \\
1 / 10(10) \\
0 / 16(0) \\
0 / 13(0) \\
0 / 13(0) \\
1 / 12(8) \\
8 / 13(62)\end{array}$ \\
\hline $\begin{array}{l}\text { Control } \\
\text { strains }\end{array}$ & $\left\{\begin{array}{l}\mathrm{A} / \mathrm{Vic} / 3 / 75 \\
\mathrm{H} 2 \mathrm{~N} 2\left\{\begin{array}{l}4 \mathrm{~A} 2 \\
\mathrm{Nil}\end{array}\right.\end{array}\right.$ & $\begin{array}{l}4.5 \times 10^{5} \\
4.5 \times 10^{5} \\
4.0 \times 10^{5}\end{array}$ & $\begin{array}{r}10 / 12(83) \\
3 / 11(27) \\
0 / 11(0)\end{array}$ & $\begin{array}{l}7 / 12(58) \\
1 / 11 \quad(9) \\
0 / 11 \quad(0)\end{array}$ \\
\hline
\end{tabular}


positive blood cultures; this result was similar to the $83 \%$ bacteraemia observed in rats previously inoculated with the control strain $\mathrm{A} / \mathrm{Victoria} / 3 / 75$. In contrast, previous infection with strains A/HK/119/77, A/USSR/92/77, A/Okuda/57-bb/3, WRL211, WRL215, WRL217 and WRL224 provoked significantly less bacteraemia with incidences of positive blood cultures of $8-23 \%$; these results were similar to that obtained for the control, attenuated strain 4A2 (table II).

Histological evidence of meningitis was observed in $75 \%$ of animals previously inoculated with strain $\mathrm{A} /$ Finland $/ 74$, and $62 \%$ of those inoculated with WRL105; again the result was similar to that obtained for the control virulent strain $\mathrm{A} /$ Victoria/3/75 (table II). The incidence of meningitis was significantly less for all other viruses tested; thus, for strain $\mathrm{A} / \mathrm{HK} / 77$ (X2 cloned) the incidence was $23 \%$, whilst for the remaining strains the incidence was $\leqslant 10 \%$ (table II).

\section{Correlation of results of influenza virus infection of infant rats with virulence for man and genetic structure}

From the results of previous studies, the indicators of influenza virus infection of infant rats that best discriminated between virulent and attenuated strains were the titres of virus in the nasal turbinates soon after infection, and the incidence of bacteraemia after challenge with HIb (Michaels et al., 1978; Mahmud et al., 1979b), these observations for the present studies are shown in table III, and are related to the gene composition of the recombinant strains investigated. Influenza virus strains A/Finland/74 and A/Victoria/75 were naturally occurring virulent strains which replicated to relatively high titre in the turbinates and the lungs of infant rats, and induced bacteraemia and meningitis in more than $80 \%$ and $50 \%$ of animals respectively. In contrast, attenuated strains $\mathrm{A} / \mathrm{Okuda} / 57$ and $\mathrm{A} / \mathrm{HK} / 119 / 77$ replicated to relatively lower titres in the turbinates of infant rats, and induced bacteraemia in less than $33 \%$ of animals Thus, for these five strains of virus, virulence for infant rats correlated with virulence for man. Recombinant strain WRL105 behaved as a virulent strain, and this result was consistent with the behaviour of this virus in human volunteers (Dr A. S. Beare, personal communication). In addition, influenza virus strains A/Okuda/57, 4A2, WRL211 and WRL216 showed relatively low virulence for infant rats, and have been reported to be attenuated in volunteer studies (Okuno and Nakamura, 1966; Dr A. S. Beare, personal communication). The results obtained for strains WRL206, WRL215, WRL217 and WRL224 suggest that they were of low virulence for infant rats, but no data are available on their properties in man.

A comparison of the virulence of the influenza viruses for man and infant rats and the genetic structure of the recombinant strains is shown in table III. Influenza virus strains WRL105 and WRL206 both replicated to relatively high titre in infant-rat turbinates, whilst other recombinants replicated to significantly lower titre: the former two strains both possessed gene 1 of strain A/Okuda/57, which also replicated to relatively high titre. Thus, replication 


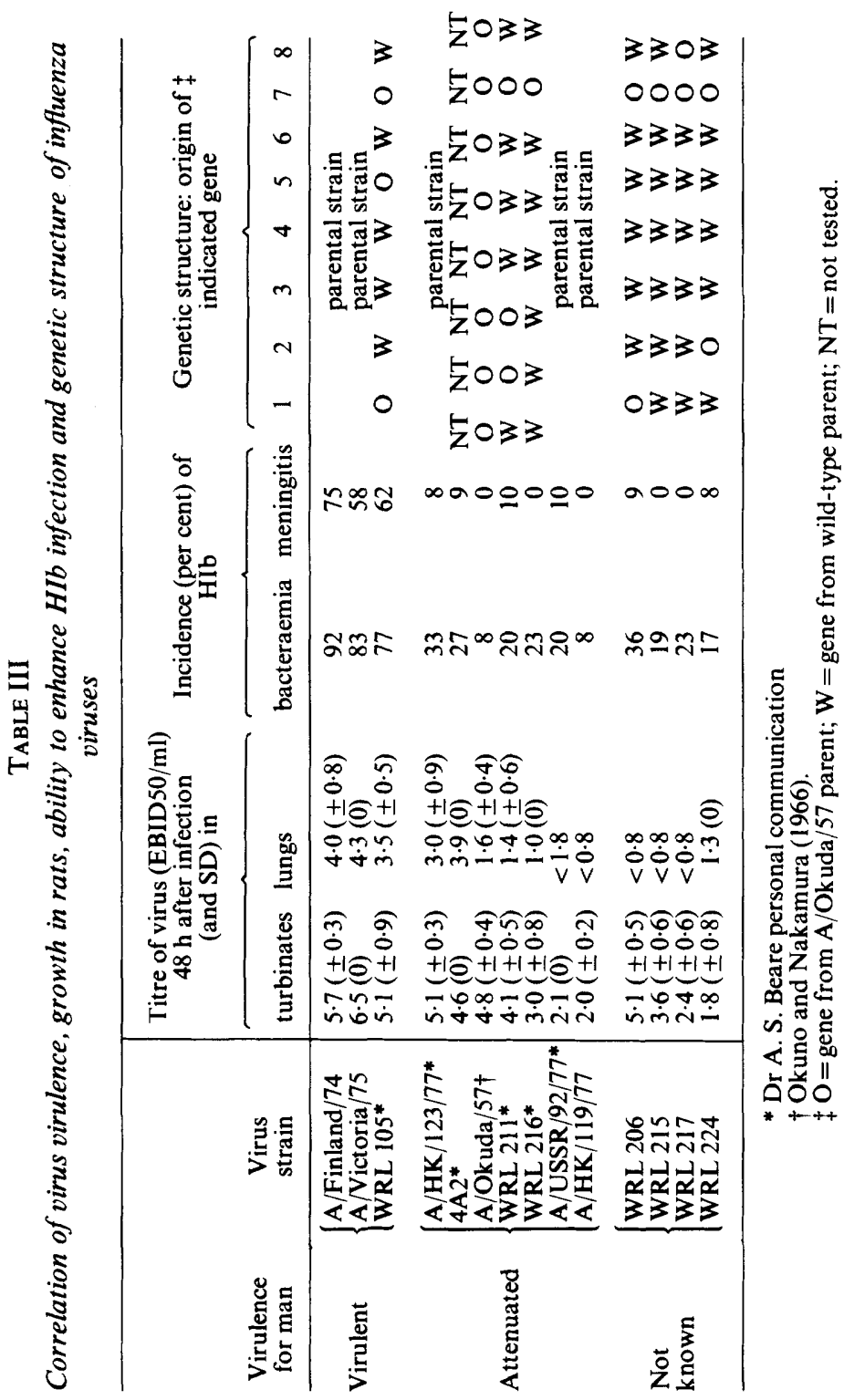


to high titre may be linked to gene 1 , but this does not imply virulence per se, because for WRL206 virus this property did not correlate with a marked enhancement of subsequent HIb infection. More studies with a wider spectrum of recombinants of varying human virulence are required to determine the gene or gene constellation associated with virulence.

\section{DisCUSSION}

The only acceptable technique for measuring the virulence of influenza virus vaccines for man at present is the inoculation of volunteers; this is a protracted procedure which delays the development of live virus vaccines for general use. Considerable advantage could be obtained from the successful development of a laboratory technique for measuring virulence for man; to this end, the replication of virus in ferrets (Lobmann et al ., 1976; Toms et al., 1976; Fenton, Jennings and Potter, 1977), virus replication in hamsters (Murphy et al., 1972) and growth in organ cultures of human ferret trachea (Mostow and Tyrrell, 1972, 1973) have been investigated as possible models. At present none of these techniques is a satisfactory alternative to volunteer studies; correlation of the results of human studies with those in tissue culture have been poor (Hara, Beare and Tyrrell, 1974), whilst too few strains have been studied in animals to allow conclusions.

Limited studies of the behaviour of influenza viruses in infant rats have suggested that the virulence of virus strains for this species may correlate with virulence for man. Thus, virulent strains of influenza virus grew to relatively high titres in rat turbinates, and infection enhanced bacteraemia and meningitis in animals subsequently inoculated with $H$. influenzae, type b; in contrast, attenuated strains of virus replicated to lower titres in rat turbinates, and did not promote subsequent bacterial infection to the same degree (Michaels $e t$ al., 1978; Mahmud et al., $1979 a$ and $b$ ). To date 19 strains of influenza virus of varying virulence for man have been investigated in rats and, except for strain $\mathrm{A} / \mathrm{PR} / 8 / 34$, the results of pathogenicity for infant rats have shown complete agreement with those of volunteer studies. However, these studies were limited to wild-type strains and A/PR/8/34 recombinants; it remained to be determined whether the technique could be applied to recombinant viruses derived by other methods. The present studies report the results of infection of infant rats with wild-type influenza viruses and recombinants of wild-type and $\mathrm{A} / \mathrm{Okuda} / 57$ strains of virus; these recombinants have been intensively investigated as candidate live virus vaccines for use in man (Morris et al., 1975; Freestone et al., 1976). Two of the strains examined, A/Finland/74 and A/Victoria/75, are reported to be virulent for volunteers; they grew to relatively high titre in infant-rat turbinates, and promoted a relatively high incidence of bacteraemia and meningitis after intranasal inoculation with HIb. These results are consistent with the behaviour of virulent strains in infant rats, as described in previous studied (Michaels et al., 1978; Mahmud et al., 1979 a and $b$ ). Influenza virus strain WRL105 also replicated to relatively high titre in rat turbinates and markedly enhanced subsequent $\mathrm{HIb}$ infection. Initial 
studies indicated that this virus was attenuated for man (McCahon, Beare and Stealey, 1976), but larger trials produced some marked and even severe clinical reactions (Moffatt et al., 1976; Fell et al., 1977); in the opinion of some observers (Campbell, Sweet and Smith, 1979; Dr A. S. Beare, personal communication), this virus should be considered virulent for man, and the present findings in infant rats support this view. In contrast, several strains of influenza virus, including three recombinant strains that had previously been shown to be attenuated for man (Okuno and Nakamura 1966; Dr A. S. Beare, personal communication), grew to lower titres in the turbinates of rats, and induced a significantly lower level of subsequent bacterial infection than the virulent strains; again these results agree with those of earlier studies, and emphasise the potential value of the rat model in the assessment of the virulence of influenza virus strains for man. Four other recombinants of strains $\mathrm{A} / \mathrm{Okuda} / 57$ and $\mathrm{A}(\mathrm{H} 1 \mathrm{N1})$, which have not been tested in volunteers, were examined in the infant rat; all these behaved as attenuated strains.

The identification of the gene(s) of influenza virus associated with virulence for man would be of great value in the preparation of attenuated virus vaccines (Almond, 1977; Oxford et al., 1978); however, a clear indication of the genetic structure that determines the virulence of these viruses for rat and man is not possible from the limited series of viruses examined in the present studies. Such results as are presented suggest that virulence is not associated with a single gene. Thus, the three recombinant influenza virus strains containing gene 1 from strain A/Okuda/57 grew to higher titre in infant-rat turbinates than the other strains tested; strain WRL105 was virulent for man, whilst the other two strains were more virulent for rats than the remaining strains that did not contain gene 1 from strain A/Okuda/57. This result suggests that gene 1 is possibly one factor in determining the virulence of influenza virus; but is not the only determinant, because strain A/Okuda/57 is non-virulent. These findings support the view that the virulence of influenza viruses is associated with a gene constellation rather than a specific gene (Rott, Orlich and Scholtissek, 1976). In addition, the constellation of genes determining virulence may vary for different series of influenza virus strains; thus, for a series of recombinants of an avian influenza virus genes 3 and 5 were relevant to virulence (Bean and Webster, 1978), whilst gene 4 coding for virus haemagglutinin was a factor determining virulence for a series of recombinants of strain A/PR/8/34 (Beare and Hall, 1971).

\section{SUMMARY}

Infant rats were infected intranasally with wild influenza virus strains, attenuated strain $\mathrm{A} / \mathrm{Okuda} / 57$ or recombinants prepared from these parents. The growth of viruses in the turbinates or lungs, and the ability of virus infections to potentiate subsequent bacterial infection by Haemophilus influen$z a e$ (HIb) were measured. The two wild strains of virus and a recombinant strain WRL105, known to be virulent for man, reached titres of $10^{5 \cdot 1}-10^{6.5}$ $\mathrm{EBID} 50 / \mathrm{ml}$ in the turbinates of infant rats $48 \mathrm{~h}$ after infection; infection by 
these viruses was followed by HIb bacteraemia in $77-92 \%$ and meningitis in $58-75 \%$ of animals. In contrast, virus strains known to be attenuated for man grew to lower titres in infant-rat turbinates and promoted a lower incidence of systemic infection by HIb than the virulent strains. A comparison of the various results of infection of infant rats with influenza virus strains of known pathogenicity for man indicated that the subsequent incidence of HIb bacteraemia was the most discriminating measurement of virus virulence; the range of yields of attenuated virus in rat turbinates overlapped that of virulent strains. These results, together with those of previous studies, indicate that the behaviour of influenza viruses in infant rats is an indication of virus virulence for man, and could provide a test of virulence that would facilitate the development of live attenuated virus vaccines for human use.

These studies were supported by a grant from the Medical Research Council.

\section{REFERENCES}

Almond, J. W. 1977. A single gene determines the host range of influenza virus. Nature, 270, 617.

BeAn, W. J. and Webster, R. G. 1978. Phenotypic properties associated with influenza genome segments. In Negative strand viruses and the host cell, edited by B.W.J. Mahy. and R.D. Barry Academic Press: London, p. 685.

Beare, A. S. and Hall, T. S. 1971. Recombinant influenza A viruses as live vaccines for man. Lancet, 2, 1271.

Campbell, D., Sweet, C. and Smith, H. 1979. Comparisons of virulence of influenza virus recombinants in ferrets in relation to their behaviour in man and their genetic constitution. J. gen. Virol., 44, 37.

FazeKas de St Groth, S., Withell, J. and Lafferty, K. J. 1958. An improved assay method for neutralizing antibodies against influenza viruses. J. Hyg., Camb., 56, 415.

Fell, P. J., Watson, N. P., O'Donnell, H. J., Simmons, R. L. and Hasell, S. K. 1977. Longer term effects of live influenza vaccine in patients with chronic pulmonary disease. Lancet, 1 , 1282 ,

Fenton, R. J., Jennings, R. and Potter, C. W. 1977. Differential response of ferrets to infection with virulent and avirulent influenza viruses: a possible marker of virus attenuation. Archs Virol., 55, 55.

Freestone, D. S., Bowker, C. H., Letley, E., Ferris, R. D., White, W. G. and Barnes, G. M. 1976. A clinical trial of WRL105 strain live attenuated influenza vaccine comparing four methods of intranasal vaccination. J. Hyg., Camb., 76, 459.

Hara, K., Beare, A. S. AND TyrRell, D. A. J. 1974. Growth and pathogenicity of influenza viruses in organ cultures of ciliated epithelium. Arch. ges. Virusforsch., 44, 227.

Hay, A. J., Bellamy, A. R., Abraham, G., Skehel, J. J., Brand, C. M. and Webster, R. G. 1977. Procedures for the characterization of the genetic material of candidate vaccine strains. Dev. biol. Stand., 39, 15.

Lobmann, M., Delem, A., Peetermans, J. and Huygelen, C. 1976. Laboratory characteristics of an attenuated influenza type A (H3N2) virus ("Alice" strain). J. Hyg., Camb., 77, 181.

McCAhon, D., BEARE, A. S. AND STEALEY, V. 1976. The production of live attenuated influenza A strains by recombination with $\mathrm{A} / \mathrm{Okuda} / 57 \mathrm{H}_{2} \mathrm{~N}_{2}$ ). Postgrad. med. J., 5, 389.

Mahmud, M. I. A., Jennings, R. AND Potter, C. W. 1979a. The infant rat as a model for the assessment of attenuation of human influenza viruses. J. med. Microbiol., 12, 43.

Mahmud, M. I. A., MaAssab, H. F., Jennings, R. and Potter, C. W. 1979b. Influenza virus infection in newborn rats: virulence of recombinant strains prepared from a cold-adapted, attenuated parent. Archs Virol., 61, 207. 
Michaels, R. H., Mahmud, M. I. A., Coup, A. J., Jennings, R. And Potter, C. W. 1978. Influenza virus infection in newborn rats: a possible marker of attenuation for man. $J$. med. Virol., 2, 253.

Moffat, M. A. J., Stealey, V. M., Freestone, D. S. and MacDonald, A. 1976. Assessment of elicited antibody responses, clinical reactions and transmissiblity of WRL105 live influenza vaccine. J. biol. Stand., 4, 91.

Morris, C. A., Freestone, D. S., Stealey, V. M., ANd Oliver, P. R. 1975. Recombinant WRL105 strain live attenuated influenza vaccine. Immunogenicity, reactivity and transmissibility. Lancet, 2, 196.

Mostow, S. R. AND TyRRELL, D. A. J. 1972. Detection of attenuation of recombinant influenza viruses in vitro. Lancet, $2,116$.

Mostow, S. R. AND TYRRELL, D. A. J., 1973. The behaviour in vitro of attenuated recombinant influenza viruses. Arch. ges. Virusforsch., 43, 385.

Murphy, B. R., Chalhub, E. G., Nusinoff, S. R. and Chanock, R. M. 1972. Temperaturesensitive mutants of influenza virus. II. Attenuation of $t s$ recombinants for man. J. inf. Dis., 126, 170.

OKuno, Y. AND NaKamura, K. 1966. Prophylactic effectiveness of live influenza vaccine in 1965. Biken J., 9, 89.

OXford, J. S., MCGeOCh, D. J., SChILd, G. C. AND BeARE, A. S. 1978. Analysis of virion RNA segments and polypeptides of influenza A virus recombinants of defined virulence. Nature, Lond., 273, 778.

ReEd, L. J., AND MuENCH, H. 1938. A simple method of estimating fifty per cent endpoints. Am. J. Hyg., 27, 493.

RotT, R., ORLICH, M. AND SCHOLTISSEK, C. 1976. Attenuation of pathogenicity of fowl plague virus by recombination with other influenza $A$ viruses non-pathogenic for fowl: non exclusive dependence of pathogenicity on hemagglutinin and neuraminidase of the virus. J. Virol., $19,54$.

Toms, G. L., Bird, R. A., Kingsman, S. M., SweEt, C. AND Smith, H. 1976. The behaviour in ferrets of two closely related clones of influenza virus of differing virulence for man. $B r . J$. exp. Path., 57, 37. 